\title{
ARTICLE
}

\section{Vegetative anatomy and mycorrhizal morphology of Schoenorchis nivea (Lindl.) Schltr., (Orchidaceae) and their adaptive signifi- cance}

\author{
Mayakrishnan Balachandar*, Ravichandran Koshila Ravi, Kandhasamy Nagaraj, \\ Thangavelu Muthukumar
}

Root and Soil Biology Laboratory, Department of Botany, Bharathiar University, Coimbatore 641 046, Tamilnadu, India

\begin{abstract}
The anatomical description of the vegetative parts (leaf, leaf sheath, stem and root) and mycorrhizal morphology of Schoenorchis nivea (Lindl.) Schltr., belonging to the subfamily Epidendroideae of Orchidaceae was investigated. Leaves were amphistomatic covered by 10-12 $\mu \mathrm{m}$ thick cuticle, stomata paracytic with small and irregular substomatal chambers. Mesophyll homogenous, composed of thin-walled chlorenchymatous cells. Banded water-storage cells abundant in the mesophyll and the largest vascular bundle occurred at the centre of the leaf. The leaf sheath has both adaxial and abaxial epidermis covered with cuticle, homogenous mesophyll, water-storage cells, raphides and vascular bundles. The stem is surrounded by a uniseriate epidermis, cortex consisting of thick-walled fibers and collateral vascular bundles scattered in the ground tissue. Cortical proliferation was evident in S. nivea stem. Root hairs present in root regions were in contact with the substratum. Root hairs frequently branched at their tips. Root possess 2-3 layered velamen, $\cap$-thickened exodermal cells, $\mathrm{O}$-thickened uniseriate endodermis, and cortex of thin-walled parenchymatous cells containing raphides and water-storage cells. Cover cells present. Xylem arches are 9-11, with vascular tissues embedded in sclerenchymatous cells. Pith composed of thick-walled sclerenchymatous cells with intercellular space. The stomatal characteristics in leaf, the size of water-storage cells and vascular bundles exhibited significant variation in different plant parts. Intact and degenerating pelotons of orchid mycorrhizal fungi were observed in the root cortical cells. The observations of the present study clearly indicate that $S$. nivea possesses several anatomical adaptations to thrive in epiphytic habitats.
\end{abstract}

Acta Biol Szeged 63(1):1-13 (2019)

\section{KEY WORDS}

anatomical characteristics cortical proliferation orchid mycorrhiza root hairs stomata water-storage cells

\section{Introduction}

The plant family Orchidaceae with approximately 25000 species distributed in 780 genera is one among the largest plant families in angiosperms (Pridgeon et al. 2009). Orchids occur in a wide range of habitats with different life forms like terrestrial, epiphytes or lithophytes (Dearnaley 2012). Generally, epiphytic habitats are stressful due to the lack of substrate that can sufficiently hold moisture and provide nutrient essential for plant growth (Adhikari et al. 2012). Nevertheless, plant species belonging to different families have adopted several strategies to tolerate and thrive in the harsh epiphytic habitats. One such adaptation of the orchids to the epiphytic conditions is the development of multi-layered dead tissue covering the roots called velamen that helps in the acquisition and storage of water under limiting conditions (Benzing 2000).
Another unique characteristic of orchids is the mutualistic association with mycorrhizal fungi. Orchids, unlike other graminaceous members, are obligately mycorrhizal either throughout or part of their lifecycle. The dependence of orchids on mycorrhizal symbiosis arises from the fact that orchids produce minute seeds that have minimal or lack seed reserves (Arditti and Ghani 2000). Mycorrhizal fungi provide essential nutrients to the orchids from the soil or substrates needed for their growth (Smith and Read 2008, Nurfadilah et al. 2013). Orchid mycorrhiza is unique by the production of highly coiled fungal hyphal structures in the root cortical cells called pelotons. These pelotons enlarge the contact surface area between fungus and the cells, but are short-lived, senesce and collapse within the host cells (Smith and Read 2008). It is presumed that green orchids during their adult stage are less mycorrhizal dependent than during their earlier stages. However, this claim was refuted in many recent 
studies where several mature green orchids were shown to adopt a mixotrophic mode of nutrition (Bertolini et al. 2014; Selosse and Martos 2014; Lallemand et al. 2019). Mycorrhizal morphology in roots of epiphytic orchids is not well studied than those of terrestrial forms despite more than $70 \%$ of orchids have an epiphytic life-form (Atwood 1986; Sathiyadash et al. 2012).

Commonly known as flea orchids, Schoenorchis belongs to the subtribe Aeridinae of tribe Vandeae, subfamily Epidendroideae of the plant family Orchidaceae. At present, there are 25 species of this genus distributed specifically in the subtropical and tropical Asia and the Western Pacific. In India, Schoenorchis is represented by five species of which Schoenorchis nivea (Lindl.) Schltr., is a small (up to $15 \mathrm{~cm}$ tall) epiphytic monopodial orchid distributed in peninsular India and Sri Lanka (Kumar and Sequiera 2000; Mathew and George 2015). Although S. nivea has no recorded economic importance, it is listed in the CITES Appendix II where trade on this species is stringently regulated to prevent utilization irreconcilable with its survival (Mathew and George 2015; ENVIS Centre on Floral Diversity 2019).

Anatomical investigations of orchids assist in resolving the problems related to the identification of plants in their vegetative stage (Kowsalya et al. 2017; Balachandar et al. 2019). Anatomy also helps to overcome the systematic problems and is a useful tool in the precise identification of plants in same genera sharing similar morphological characteristics (Kowsalya et al. 2017). Though detailed observation of vegetative anatomy of Aeridineae taxa like Acampe, Amesiella, Chiloschista, Microtatorchis, Neofinetia, Phalaenopsis, Taeniophyllum, Trichoglottis, and Vanda are available (Carlsward et al. 2006; Carlsward 2014; Kowsalya et al. 2017) the vegetative anatomy of members belonging to Schoenorchis are unknown except for a couple of studies involving foliar and nectary anatomical investigations (Stpiczyńska et al. 2011; Angela et al. 2015). The leaf anatomy of Schoenorchis gemmata (Lindl.) J. J. Sm., along with five other terete-leaved orchids was examined by Angela et al. (2015) to see if these orchids exhibited any xeromorphic characters. The leaves of $S$. gemmata were amphistomatic and the stomata were of a paracytic type. Moreover, the leaves were broadly V-shaped, cuticle ridged, adaxial cuticle thicker than the abaxial, presence of cuticular papillae, epidermal cells spherical to polygonal, presence of specialized water-storage cells with banded thickenings, small and large vascular bundles distributed together, and sclerenchymatous tissue covering both xylem and phloem. From these results, it was concluded that $S$. gemmata like all other terete-leaved orchids examined exhibited xeromorphic characters that were directed towards efficient use of water for survival in water stressed environments (Angela et al. 2015). A study on the anatomy of the nectary spurs in the entomophilous flowers of S. gemmata pollinated by hymenoptera indicated the absence of secretary trichomes, and a very short and saccate spurs with glabrous to a minutely papillose inner surface (Stpiczyńska et al. 2011).

As there is paucity of information on the anatomy of Schoenorchis in general we examined the anatomy of the vegetative structures of $S$. nivea growing in the Western Ghats region of southern India. Moreover, we also determined the various adaptive characters exhibited by $S$. nivea and recorded the extent of variation in similar structures occurring in different parts of the plant. In addition, the mycorrhizal morphology and the extent of mycorrhizal association were also studied in S. nivea.

\section{Materials and method}

Plant samples of $S$. nivea were collected during October 2018 from Indian Cardamom Research Institute campus $\left(09^{\circ} 05^{\prime} \mathrm{N}\right.$ and $\left.77^{\circ} 09^{\prime} \mathrm{E}\right)$ located at the Myladumpara of Idukki district under Kerala state, peninsular India. The campus located at an altitude of 1050-1060 m a.s.l., spreads over an area of 64.60 ha with undulating terrain consisting of hills and valleys covered by lush evergreen forests (Balan and Harikrishnan 2017). This region is characterized by a cool and humid climate with an average maximum and minimum temperature of $25.70{ }^{\circ} \mathrm{C}$ and $17.05{ }^{\circ} \mathrm{C}$, respectively. The hottest days occur during April-May and the coolest days occur between December-January. The relative humidity ranges from $90 \%$ to $96 \%$ and the average annual precipitation is $2153 \mathrm{~mm}$. The rainfall data for 2007-2016 indicate that the amount of rainfall received consistently decline in the alternate years (Balan and Harikrishnan 2017). The floristic diversity of the site indicates the presence of 392 angiospermic taxa in 303 genera under 94 families consisting of both indigenous and naturalized flora. This angiospermic diversity also includes 15 orchids belonging to Aerides, Bulbophyllum, Cottonia, Dendrobium, Disperis, Eria, Liparis, Luisia, Oberonia, Papilionanthe, Polystachya, Schoenorchis, Sirhookera, Thelasis and Trias (Balan and Harikrishnan 2017).

Four mature plants of $S$. nivea were collected of which one plant was in late flowering phase. The specimen in flowering was used for authentication. The specimens were authenticated by the Botanical Survey of India, Southern Circle, Coimbatore, India and a voucher was deposited in the Bharati Herbarium, Department of Botany, Bharathiar University, Coimbatore, India (accession number: 007740). The plant samples were placed in an icebox and transported to the laboratory. In the lab, plants were washed thoroughly free of dirt and attached debris prior to sectioning. For uniformity, fully opened fourth 


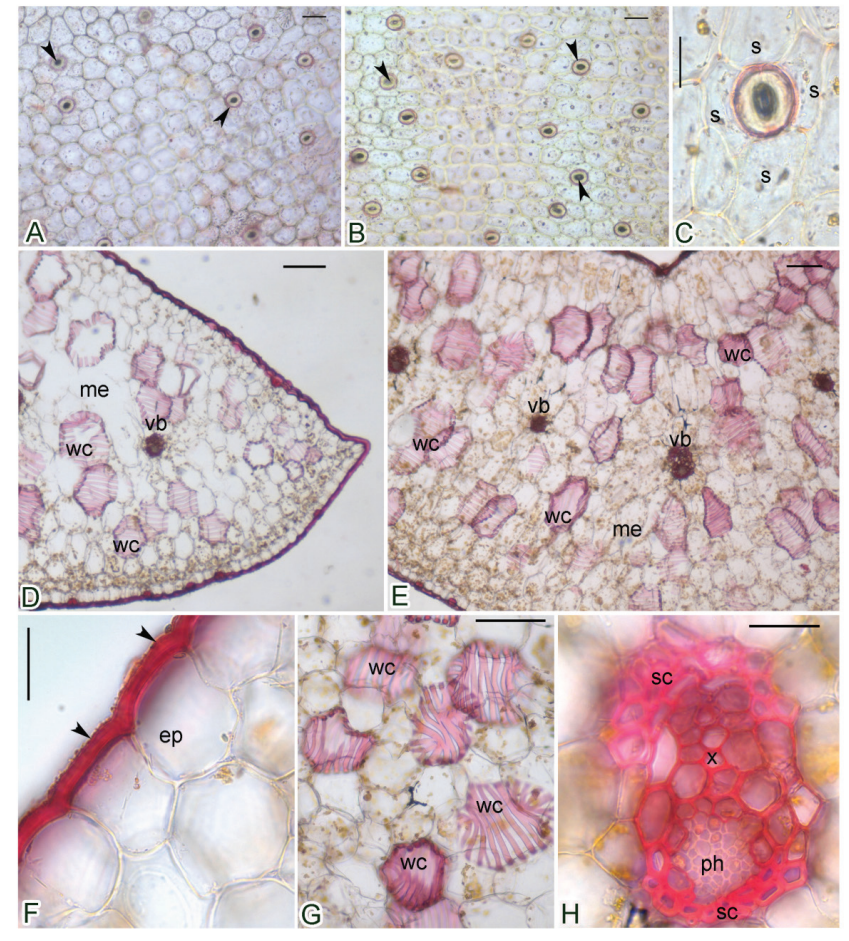

Figure 1. Leaf anatomy of Schoenorchis nivea $(A, B)$ Epidermal peeling of leaf showing stomata (black arrow heads) on the adaxial (A) and abaxial (B) surface (C) stomata with guard cells and subsidiary cells; (D-E) cross section of leaf showing epidermis, mesophyll, vascular bundle and water- storage cells; (F) epidermis with cuticle (black arrow heads); (G) banded water-storage cells; $(\mathrm{H})$ vascular bundle with phloem and xylem capped by sclerenchymatous cells.

ep $=$ epidermis, me $=$ mesophyll, $\mathrm{ph}=$ phloem, $\mathrm{s}=$ subsidiary cells, $\mathrm{sc}$ = sclerenchymatous cells, $v b=$ vascular bundle, $w c=$ water-storage cells, $x=$ xylem. Scale bars $=50 \mu \mathrm{m}(A, B, D, E, G)$ and $30 \mu m(C, F, H)$.

leaf from the tip, $1-\mathrm{cm}$ stem or root from $3 \mathrm{~cm}$ below the shoot or root tip was used in the study. The transverse sections for histological observations were prepared by freehand sectioning (Lux et al. 2005). The sections of desired plant parts were made using smooth strokes with a sharp razor blade and transferred onto a drop of water on a microscopic slide. The water was later removed using a filter paper and various types of stains such as safranin, Iodine-Potassium iodide, Phloroglucinol- $\mathrm{HCl}$, and Toludine Blue $\mathrm{O}$ were used for identifying cell inclusions and other compounds such as cutin, lignin, starch grains, and polysaccharides (Johanson 1940). For the observation of epidermal surface, $1 \mathrm{~cm}$ square leaf pieces were placed in Jeffrey's maceration solution for 72 hours at $35^{\circ} \mathrm{C}(\mathrm{Kigkr}$ 1971). The specimens were later washed, stained with safranin and examined under an Olympus BX51 light microscope (Olympus, Tokyo, Japan). Cellular details like the cuticle thickness, length and width of different types of cells, and vascular bundles were measured us- ing a calibrated ocular micrometer. The stomatal index (SI \%) was calculated by using the formula $(\mathrm{S} / \mathrm{S}+\mathrm{E}) \times 100$ according to Salisbury (1927) where S and E denote the number of stomata and epidermal cells. The stomatal type was determined according to Van Cotthem (1970).

For estimation of mycorrhizal colonization, the roots were cut into $1 \mathrm{~cm}$ long bits, cleared by boiling in $2.5 \%$ $\mathrm{KOH}$ at $100{ }^{\circ} \mathrm{C}$ for 60 minutes. The cleared roots were washed and treated with $5 \mathrm{~N} \mathrm{HCl}$ for 30 minutes. The acidified roots were stained by placing them in trypan blue $(0.05 \%$, w/v) solution overnight (Koske and Gemma 1989). Squashes of stained root bits were prepared and observed for the presence orchid mycorrhizal fungal structures. McGonigle et al. (1990) magnified intersection method was used to calculate the percentage of total root length colonization and root length containing intact and degenerating pelotons. The pelotons were considered intact when the fungal hyphae were undamaged and degenerating when the hyphae were damaged or were a crumbling mass.

To determine the extent of variation in structures occurring in different plant parts we performed statistical analysis [t-test or Analysis of Variance (ANOVA)] using SPSS version 9.0 for windows (SPSS Inc., Chicago, USA). The data were examined for homogeneity prior to statistical analysis (Levene's test) and Post Hoc analysis (Duncan's Multiple Range Test) was performed when the Fishers values were found significant. Box plot analysis was performed for assessing the extent of mycorrhizal colonization. The values presented in tables as mean.

\section{Results}

\section{Leaf}

Leaves are fleshy and succulent. Stomata are of paracytic type observed on both the leaf surfaces with two subsidiary cells parallel to the guard cells (Fig. $1 \mathrm{~A}-\mathrm{C}$ ) The abaxial leaf surface had significantly more stomata $\left(19-21 \mathrm{~mm}^{-2}\right)$ than the abaxial surface $\left(42-47 \mathrm{~mm}^{-2}\right)$. The stomatal index (SI \%) on the abaxial surface (8.62\%) was significantly higher than the adaxial surface (5.51\%). Similarly, the length and width of guard cells $(0.87 \%$ and $18.92 \%)$ and stomatal pores (47.05\% and $43.05 \%)$ were significantly greater on the adaxial surface than abaxial leaf surface (Table 1). Cuticle ridged, 10-12 $\mu \mathrm{m}$ thick, present on both adaxial and abaxial surfaces (Fig. 1D). The thickness of the cuticle was $11.59 \%$ higher on the adaxial than the abaxial surface. Cells of adaxial and abaxial epidermis were compactly arranged. Cell wall on the outer tangential surface much thicker than the other walls. The epidermal cells on the adaxial surface were $25.03 \%$ longer and $27.77 \%$ wider respectively when compared to the abaxial 
surface of the leaf (Table 1). Substomatal chambers small and irregular. Hypodermis and fiber bundles absent. Mesophyll cells: homogenous, chlorenchymatous, and composed of thin-walled, elongated to oval-shaped cells (Fig. 1D-E). Banded water-storage cells present in the mesophyll (Fig. 1G). Bundle sheath indistinct. Vascular bundles oriented towards the upper epidermis. Largest vascular bundle present in the centre of the leaf. Xylem and phloem are covered by sclerenchymatous cells (Fig. $1 \mathrm{H})$. The walls of sclerenchymatous cells enclosing the phloem tissues are more thickened than those enclosing the xylem. Stegmata absent in the sclerenchyma cells of the xylem and phloem poles.

Table 1. Cell dimensions in transverse section of Schoenorchis nivea leaf and leaf sheath.

\begin{tabular}{|c|c|c|}
\hline Variables & Leaf (L) & Leaf sheath (LS) \\
\hline \multicolumn{3}{|l|}{ Stomata number $\left(\mathrm{mm}^{2}\right)$} \\
\hline Adaxial & $21.76 \pm 1.52$ & -- \\
\hline Abaxial & $47.06 \pm 1.37$ & -- \\
\hline \multicolumn{3}{|l|}{ Guard cell (adaxial) ( $\mu \mathrm{m})$} \\
\hline Length & $37.67 \pm 0.17$ & -- \\
\hline Width & $9.67 \pm 0.33$ & -- \\
\hline \multicolumn{3}{|l|}{ Guard cell (abaxial) $(\mu \mathrm{m})$} \\
\hline Length & $38.00 \pm 0.50$ & -- \\
\hline Width & $11.50 \pm 0.41$ & -- \\
\hline \multicolumn{3}{|l|}{ Stomatal pore length $(\mu \mathrm{m})$} \\
\hline Adaxial & $17.00 \pm 0.27$ & -- \\
\hline Abaxial & $13.17 \pm 0.30$ & -- \\
\hline \multicolumn{3}{|l|}{ Stomatal pore width $(\mu \mathrm{m})$} \\
\hline Adaxial & $9.00 \pm 0.48$ & -- \\
\hline Abaxial & $7.50 \pm 0.42$ & -- \\
\hline \multicolumn{3}{|l|}{ Cuticle thickness $(\mu \mathrm{m})$} \\
\hline Adaxial & $12.25 \pm 0.51$ & $8.58 \pm 0.23$ \\
\hline Abaxial & $10.83 \pm 0.64$ & $19.17 \pm 0.78$ \\
\hline \multicolumn{3}{|l|}{ Epidermis (adaxial) $(\mu \mathrm{m})$} \\
\hline Cell Length & $53.25 \pm 1.19$ & $16.67 \pm 0.77$ \\
\hline Cell Width & $51.92 \pm 1.56$ & $33.50 \pm 1.25$ \\
\hline \multicolumn{3}{|l|}{ Epidermis (abaxial) $(\mu \mathrm{m})$} \\
\hline Cell length & $39.92 \pm 0.62$ & $47.33 \pm 1.09$ \\
\hline Cell width & $37.50 \pm 1.35$ & $46.00 \pm 0.88$ \\
\hline \multicolumn{3}{|l|}{ Mesophyll ( $\mu \mathrm{m})$} \\
\hline Cell length & $135.42 \pm 5.60$ & $42.83 \pm 1.02$ \\
\hline Cell width & $76.58 \pm 2.27$ & $59.92 \pm 1.46$ \\
\hline \multicolumn{3}{|l|}{ Water-storage cell $(\mu \mathrm{m})$} \\
\hline Length & $168.25 \pm 6.60$ & $39.42 \pm 0.84$ \\
\hline Width & $127.00 \pm 3.77$ & $99.33 \pm 4.24$ \\
\hline \multicolumn{3}{|l|}{ Vascular bundle $(\mu \mathrm{m})$} \\
\hline Length & $99.50 \pm 5.22$ & $98.67 \pm 2.93$ \\
\hline Width & $69.00 \pm 3.09$ & $87.08 \pm 3.67$ \\
\hline Vascular bundle (No. per L/LS) & $9.13 \pm 0.83$ & $11.40 \pm 0.21$ \\
\hline
\end{tabular}

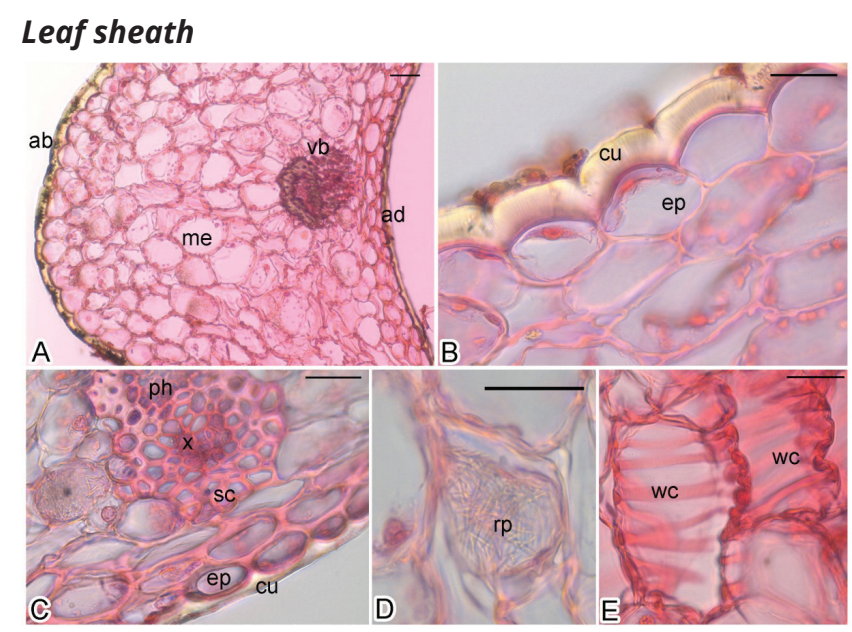

Figure 2. Leaf sheath anatomy of Schoenorchis nivea (A) cross section of leaf sheath showing adaxial and abaxial epidermis, mesophyll and vascular bundle; (B) epidermis with thick cuticle on the abaxial side; (C) epidermis and cuticle on the adaxial side and vascular bundle with phloem and xylem capped by sclerenchymatous cells; (D) raphides present in the mesophyll cell; (E) water-storage cell with banded thickening.

$\mathrm{ab}=$ abaxial, $\mathrm{ad}=$ adaxial, $\mathrm{cu}=$ cuticle, $\mathrm{ep}=$ epidermis, ep = epidermis, me $=$ mesophyll, $\mathrm{ph}=$ phloem, $\mathrm{rp}=$ raphides, $\mathrm{sc}=$ sclerenchymatous cells, $v b=$ vascular bundle, $w c=$ water-storage cell, $x=$ xylem. Scale bars $=50 \mu \mathrm{m}(\mathrm{A})$ and $30 \mu \mathrm{m}(\mathrm{B}-\mathrm{E})$.

Stomata absent. Cuticle present on both adaxial and abaxial surfaces. Cuticle heavily ridged along the contours and is twice more thickened on the abaxial side when compared to the adaxial surface (Table 1). Adaxial epidermis uniseriate, compactly arranged with thickwalled rectangular cells. Abaxial epidermis single layered, composed of thin-walled round to oval-shaped cells (Fig. $2 \mathrm{~A}, \mathrm{~B})$. Both radial and tangential walls of the adaxial epidermal cells are much thicker than those on the abaxial side of the leaf sheath. The dimension including length (64.53\%) and width (27.17\%) of the abaxial epidermal cell is significantly larger than the adaxial epidermis (Table 1). Hypodermis absent. Mesophyll undifferentiated into palisade and spongy parenchyma, chlorenchymatous. Mesophyll cells are periclinally oriented, smaller and compactly arranged towards the adaxial surface. Idioblasts containing raphides and banded water-storage cells are present in the mesophyll (Fig. 2D, E). Vascular bundles oriented towards the adaxial surface. Xylem and phloem tissues are surrounded by sclerenchymatous cells. The phloem tissue is covered by thickened sclerenchymatous cells (Fig. 2C).

\section{Stem}

Stem consists of cuticle, epidermis, cortex, ground tissue containing vascular bundles (Fig. 3A). Stem circular in shape and covered by cuticle of $10-13 \mu \mathrm{m}$ thickness (Table 
Vegetative anatomy of Schoenorchis nivea

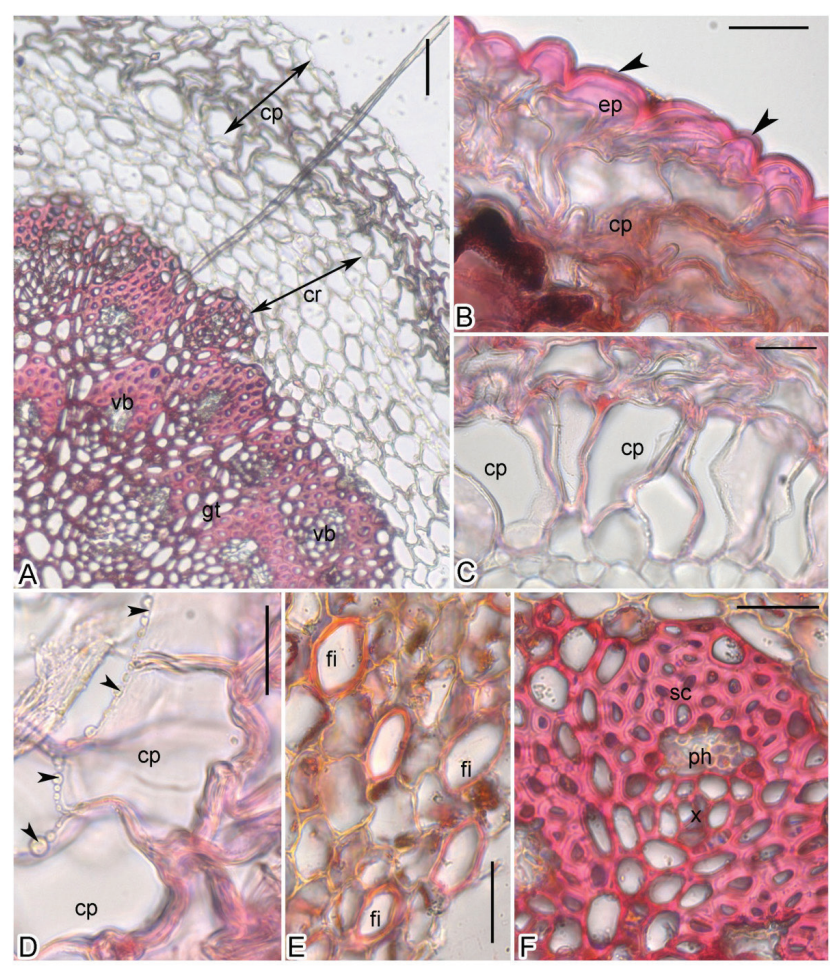

Figure 3. Stem anatomy of Schoenorchis nivea (A) transverse section of stem showing cortical proliferation, cortex and vascular bundle embedded in ground tissue; (B) epidermis covered by cuticle (black arrow heads) and cortical proliferation; (C) elongated cortical cells during cortical proliferation; (D) vesicles (black arrow heads) arranged close to the expanding cortical cell walls in cortical proliferation; (E) fibers in the cortical region; $(F)$ vascular bundle with phloem and xylem capped by sclerenchymatous tissue .

$\mathrm{cp}=$ cortical proliferation, $\mathrm{cr}=$ cortex, ep = epidermis, fi = fibers, gt = ground tissue, $\mathrm{ph}=$ phloem; $\mathrm{sc}=$ sclerenchymatous cell, $\mathrm{vb}=$ vascular bundle, $x=$ xylem. Scale bars $=50 \mu \mathrm{m}(\mathrm{A}), 30 \mu \mathrm{m}(\mathrm{B}-\mathrm{F})$.

2). Epidermis single layered, consisting of compactly arranged parenchymatous cells (Fig. 3B). Cortex subtending the epidermis is 6-9 layered and composed of thin-walled parenchymatous cells. Thick-walled fibers are present in the cortex (Fig. 3E). This region is characterized by the absence of vascular bundles. Ground tissue: comprising of circular to angular, thick-walled sclerenchymatous cells enclosing triangular intercellular air spaces. Cortical proliferation is evident during the process of stem thickening (Fig. 3B-D). The outer most cells of the cortical region expand radially which is later on followed by tangential expansion. During the cortical proliferation, small vesicle-like structures are formed which could help in lignifications (Fig. 3D). The cell walls of expanding cells get isolated from the primary cortical cells and buckles up providing thickness to the stem. Vascular bundles are collateral and scattered in the ground tissue. Larger vascular bundles are present at the central portion and
Table 2. Cell dimensions in transverse section of Schoenorchis nivea stem.

\begin{tabular}{ll}
\hline Variables & Measurements $(\mu \mathrm{m})$ \\
\hline $\begin{array}{l}\text { Cuticle thickening } \\
\text { Epidermis }\end{array}$ & $13.17 \pm 0.27$ \\
Cell length & $19.83 \pm 0.87$ \\
Cell width & $17.33 \pm 0.75$ \\
Hypodermis & \\
Cell length & $31.08 \pm 1.05$ \\
Cell width & $32.58 \pm 0.99$ \\
Ground tissue & \\
Cell length & $26.42 \pm 0.99$ \\
Cell width & $25.67 \pm 1.31$ \\
Vascular bundle & \\
length & $95.75 \pm 2.37$ \\
width & $80.17 \pm 2.02$ \\
\hline
\end{tabular}

smaller ones are oriented towards the peripheral region of the ground tissue. Xylem and phloem tissues are enclosed by thick-walled sclerenchymatous tissues (Fig. 3F).

\section{Root}

Roots are mostly attached to the substratum. Circular in outline when aerial and the region attached to the substratum is not much flattened. Root hairs present in the portions of the roots that were in contact with the substratum. Root hairs are frequently branched at their tips (Fig. 4A). Velamen: 2-3 layered, differentiated into exovelamen and endovelamen. The cells of both exovelamen and endovelamen possess striations and both the radial as well as the tangential walls are thicker (Fig. 4B). The cells of endovelamen are longer when compared to exovelamen whereas; the exovelamen cells were wider than those of endovelamen (Table 3). Exodermis: Uniseriate, dimorphic and $\cap$-thickened and composed of both long and short cells. Long-cells of exodermis are thick-walled. Thin-walled short passage cells are present in-between the long exodermal cells (Fig. 4C). Tilosomes absent. Cover cells present above the passage cells. Cortex is 6-8 layered and composed of thin-walled parenchymatous cells (Fig. 4B). Raphides and water-storage cells are abundant in the cortex (Fig. 4D, E). Endodermis is O-thickened and present opposite to the phloem tissue and interrupted by thin-walled passage cells oriented opposite to the xylem. Pericycle located opposite to the xylem is thin-walled and thick-walled pericycle is oriented opposite to the phloem. Xylem and phloem elements are embedded in sclerenchymatous tissues. Pith consists of thick-walled cells with intercellular space of varied shapes (Fig. 4F). 
Table 3. Cell dimensions in transverse section of Schoenorchis nivea root.

\begin{tabular}{|c|c|}
\hline Variables & Measurements $(\mu \mathrm{m})$ \\
\hline \multicolumn{2}{|l|}{ Root hair } \\
\hline Length & $146.17 \pm 5.34$ \\
\hline Width & $47.92 \pm 1.41$ \\
\hline \multicolumn{2}{|l|}{ Exovelamen } \\
\hline Cell length & $29.25 \pm 1.09$ \\
\hline Cell width & $30.33 \pm 1.03$ \\
\hline \multicolumn{2}{|l|}{ Endovelamen } \\
\hline Cell length & $50.25 \pm 1.68$ \\
\hline Cell width & $23.67 \pm 0.65$ \\
\hline \multicolumn{2}{|l|}{ Exodermis } \\
\hline Cell length & $54.67 \pm 1.97$ \\
\hline Cell width & $33.42 \pm 1.19$ \\
\hline \multicolumn{2}{|l|}{ Cortex } \\
\hline Cell length & $53.50 \pm 2.68$ \\
\hline Cell width & $45.50 \pm 1.29$ \\
\hline \multicolumn{2}{|l|}{ Water cell } \\
\hline Length & $97.42 \pm 2.84$ \\
\hline Width & $68.50 \pm 2.46$ \\
\hline \multicolumn{2}{|l|}{ Endodermis } \\
\hline Cell length & $26.00 \pm 0.68$ \\
\hline Cell width & $20.00 \pm 0.74$ \\
\hline \multicolumn{2}{|l|}{ Passage cell } \\
\hline Length & $15.75 \pm 0.71$ \\
\hline Width & $10.08 \pm 0.46$ \\
\hline \multicolumn{2}{|l|}{ Meta xylem } \\
\hline Cell length & $13.50 \pm 0.23$ \\
\hline Cell width & $12.50 \pm 0.24$ \\
\hline \multicolumn{2}{|l|}{ Phloem patch } \\
\hline Length & $24.08 \pm 0.53$ \\
\hline Width & $13.08 \pm 0.57$ \\
\hline \multicolumn{2}{|l|}{ Pith } \\
\hline Cell length & $15.08 \pm 0.58$ \\
\hline Cell width & $14.50 \pm 0.57$ \\
\hline
\end{tabular}

\section{Mycorrhizal morphology and extent of colonization}

Mycorrhizal colonization was observed in the roots that were attached to the substrate. The fungal hyphae entered the roots through the root hairs and transacted through the velamen and the passage cells of the exodermis into the cortex (Fig. 5A, B). Regularly septate hyphae, hyphal coils, microsclerotia and moniliform cells were observed in the velamen tissue (Fig. 5C, F). Both intact and degenerating pelotons were present in the root cortical cells (Fig. $5 \mathrm{D}, \mathrm{E})$. The proportion of root length with degeneration pelotons was several folds higher than the root length with intact pelotons (Fig. 6). Root infection by nematodes was occasionally seen (Fig. 5G). Nevertheless, no distortion or damage was visible in roots containing nematodes.

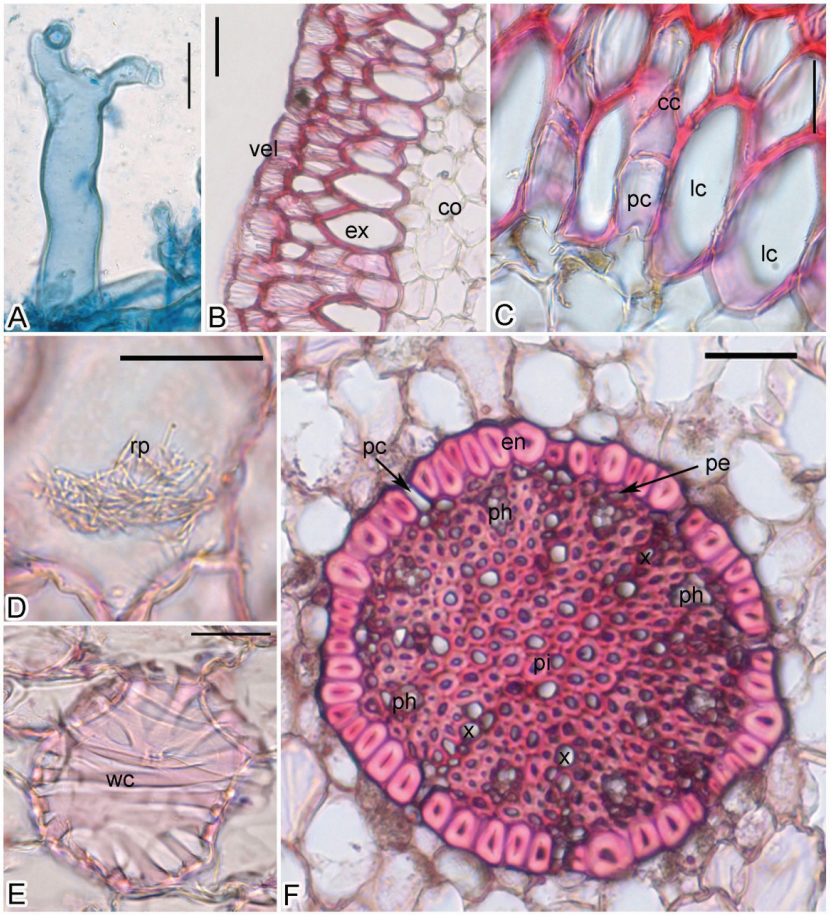

Figure 4. Root anatomy of Schoenorchis nivea (A) branched root hair; (B) transverse section of root showing velamen, exodermis and cortex; $(C)$ exodermis long cell, cover cell and passage cell; (D) raphides in cortical cell; (E) banded water-storage cell; (F) stele showing O- thickened endodermis, thin-walled passage cell, pericycle, phloem, xylem, and thick-walled pith.

$\mathrm{cc}=$ cover cell, $\mathrm{co}=$ cortex, en = endodermis, ex = exodermis, $\mathrm{Ic}=$ long cell, $\mathrm{pc}=$ passage cell; $\mathrm{pe}=$ pericycle, $\mathrm{ph}=$ phloem, $\mathrm{pi}=\mathrm{pith}, \mathrm{rp}=$ raphides, vel $=$ velamen, $w c=$ water-storage cell, $x=x y l e m$. Scale bars $=50 \mu \mathrm{m}(\mathrm{B}, \mathrm{F})$ and $30 \mu \mathrm{m}(\mathrm{A}, \mathrm{C}-\mathrm{E})$.

The orchid mycorrhizal fungal structures including intact pelotons and degenerating pelotons varied significantly $\left(\mathrm{F}_{2,8}=72.756 ; \mathrm{P}<0.001\right)$ in S. nivea. The percentage of root length colonization with degenerating pelotons was higher than the percentage of root length colonization with intact pelotons. The percentage of total root length colonization was $50.15 \%$ (Fig. 6).

\section{Comparison of common structures in plant parts}

The stomatal characteristics including the width of the guard cell, size of the stomatal pore and the number of stomata were significantly different on both adaxial and abaxial surface of the leaf except for guard cell length. The cell dimension of epidermal cells, cuticle thickening, number and width of vascular bundles on adaxial and abaxial surfaces had significant variation between leaf and leaf sheath except for the length of vascular bundles (Table 4). Similarly, the size of the water-storage cells and width of the vascular bundles also exhibited significant variation except for the length of the vascular bundles 


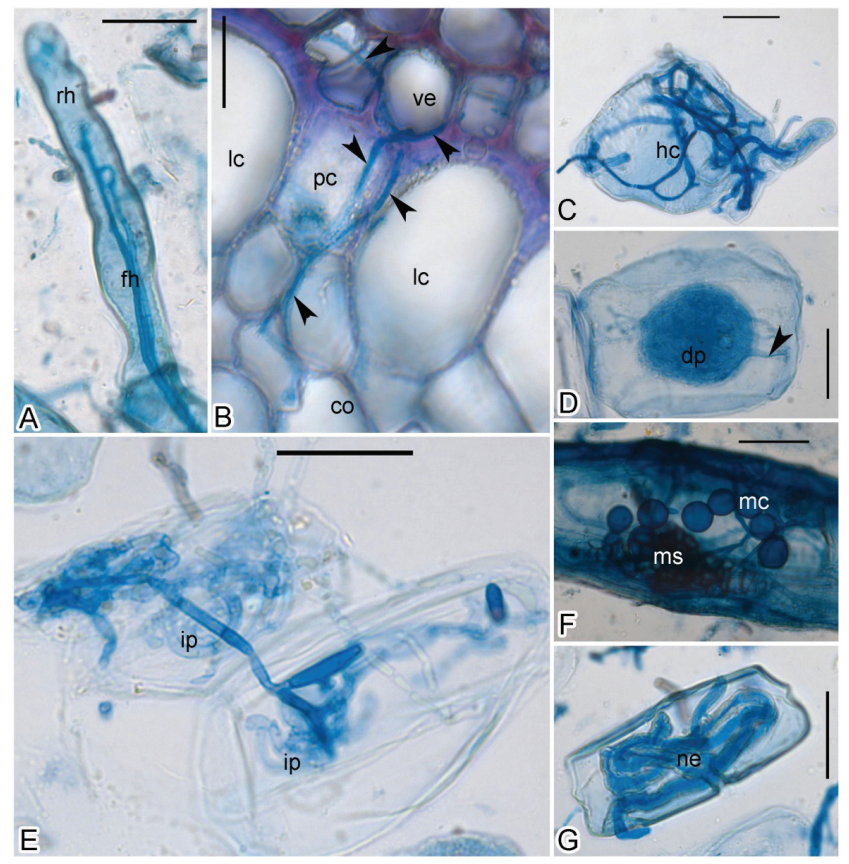

Figure 5. Mycorrhizal morphology of Schoenorchis nivea root. (A) fungal hyphae within root hair; (B) fungal hyphae (black arrow heads) traversing the velamen into the cortex through the passage cell of the exodermis; (C) hyphal coil in velamen cell; (D) degenerating peloton with hyphal remnants (black arrow head); (E) intact pelotons in cortical cells; (F) moniliform cells and microsclerotia; $(\mathrm{G})$ nematode in cortical cell. $\mathrm{co}=$ cortex, $\mathrm{dp}=$ degenerating peloton, $\mathrm{fh}=$ fungal hyphae, $\mathrm{hc}=$ hyphal coil, ip = intact pelotons, lc = long cell, $\mathrm{mc}=$ moniliform cells, $\mathrm{ms}$ $=$ microsclerotia, $\mathrm{ne}=$ nematode, $\mathrm{pc}=$ passage cell, $\mathrm{rh}=$ root hair, ve $=$ velamen. Scale bars $=50 \mu \mathrm{m}(\mathrm{B})$ and $30 \mu \mathrm{m}(\mathrm{A}, \mathrm{C}-\mathrm{F})$.

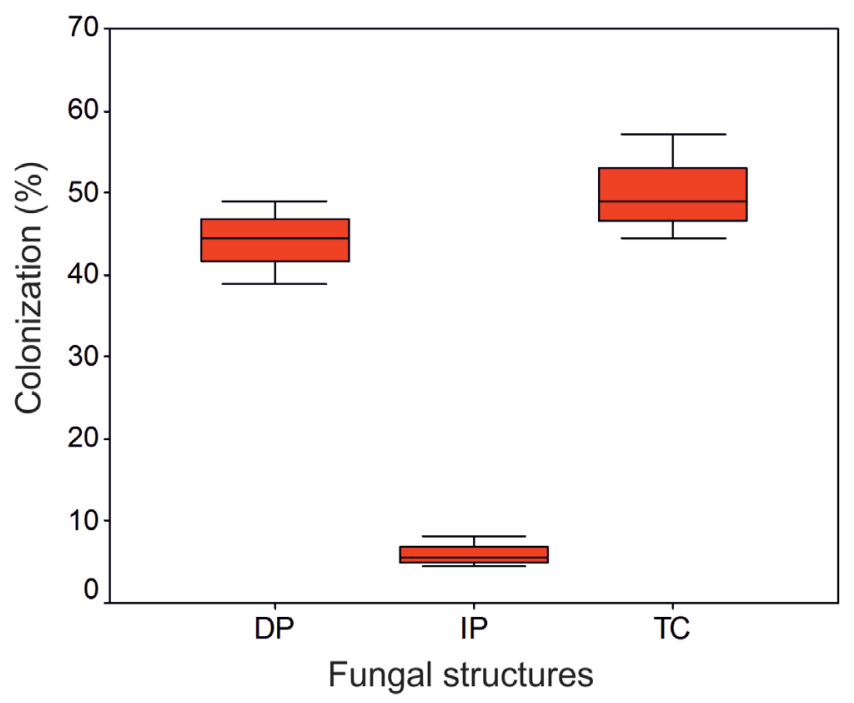

Figure 6. Box plots showing the distribution of total mycorrhizal colonization (TC) and root length with degenerating (DP) and intact (IP) pelotons in Schoenorchis nivea root.
Table 4. Comparison of stomata, epidermis and cuticle characteristics using student's t-test.

\begin{tabular}{|c|c|c|c|}
\hline \multicolumn{4}{|c|}{ Stomata (adaxial and abaxial) } \\
\hline Variables & t-value & df & Significance (2-tailed) \\
\hline \multicolumn{4}{|l|}{ Guard cell } \\
\hline Length & -0.695 & 14 & 0.499 \\
\hline Width & -3.556 & 14 & 0.003 \\
\hline \multicolumn{4}{|l|}{ Stomata pore } \\
\hline Length & 11.500 & 14 & 0.001 \\
\hline Width & 2.806 & 14 & 0.014 \\
\hline Stomata number & -21.767 & 14 & 0.001 \\
\hline Stomatal index (\%) & 9.953 & 14 & 0.001 \\
\hline \multicolumn{4}{|c|}{ Leaf and Leaf sheath } \\
\hline \multicolumn{4}{|l|}{ Upper epidermis } \\
\hline Cell length & -7.891 & 29 & 0.001 \\
\hline Cell width & 28.039 & 29 & 0.001 \\
\hline \multicolumn{4}{|l|}{ Lower epidermis } \\
\hline Cell length & -5.877 & 29 & 0.001 \\
\hline Cell width & 9.062 & 29 & 0.001 \\
\hline \multicolumn{4}{|l|}{ Cuticle thickening } \\
\hline Lower side & -8.118 & 29 & 0.001 \\
\hline Upper side & 6.279 & 29 & 0.001 \\
\hline \multicolumn{4}{|l|}{ Vascular bundle } \\
\hline Length & 0.141 & 29 & 0.889 \\
\hline Width & -3.935 & 29 & 0.001 \\
\hline Number & -2.639 & 14 & 0.019 \\
\hline
\end{tabular}

among plant parts (Table 5). A three-way ANOVA involving cuticle thickness, length and breadth of cells (cell dimension) of adaxial and abaxial surfaces (sides) of leaf and leaf sheath (plant parts) indicated a significant variation among these variables (Table 6). In addition, the two-way and three-way interactions among these factors were also highly significant.

\section{Discussion}

Schoenorchis nivea exhibited several adaptive characteristics to thrive in the harsh epiphytic habitats. Cuticle, the key barrier between the comparable dry atmosphere and the hydrated aerial parts of plants covered all the airy parts of $S$. nivea. Cuticular thickness covering the leaves can substantially vary among plant species in spite of environmental influence on this anatomical trait (Zhong et al. 2018). This is clearly evident in the present study where the cuticle covering the adaxial and abaxial surfaces of the leaves in S. nivea were respectively $9.26 \%$ and $8.96 \%$ thinner those of S. gemmata examined from Tamenglong, Manipur, India (Angela et al. 2015). The altitudes and temperature ranges of Myladumpara, Kerala and Tamenglong, Mani- 
Balachandar et al.

Table 5. Characteristics of water-storage cells and vascular bundle in different parts of Schoenorchis nivea.

\begin{tabular}{lllll}
\hline \multirow{2}{*}{ Plant organs } & \multicolumn{2}{c}{ Water-storage cell $(\mu \mathrm{m})$} & \multicolumn{2}{c}{ Vascular bundle $(\mu \mathrm{m})$} \\
\cline { 2 - 5 } & Length & Width & Width \\
\hline Leaf & $168.25 \pm 6.59 \mathrm{a}$ & $127.00 \pm 3.77 \mathrm{a}$ & $99.50 \pm 5.22 \mathrm{a}$ & $69.00 \pm 3.09 \mathrm{a}$ \\
Leaf sheath & $39.42 \pm 0.83 \mathrm{c}$ & $99.33 \pm 4.23 \mathrm{~b}$ & $98.67 \pm 2.92 \mathrm{a}$ & $87.08 \pm 3.67 \mathrm{~b}$ \\
Stem & - & - & $95.75 \pm 2.37 \mathrm{a}$ & $80.17 \pm 2.02 \mathrm{~b}$ \\
Root & $97.42 \pm 2.84 \mathrm{~b}$ & $68.50 \pm 2.45 \mathrm{c}$ & - & - \\
\hline df- 29 & $238.793^{* *}$ & $67.226^{\star \star *}$ & $0.281 \mathrm{~ns}$ & $9.214^{* \star *}$ \\
\hline
\end{tabular}

Means \pm S.E., in a row followed by a same letter(s) are not significantly ( $P>0.05$ ) different according to Duncan's Multiple Range Test. $\star * \star$ significant at $0.01 \%$, ns- not significant

pur are almost similar except for Tamenglong receiving twice the average rainfall of Myladumpara. Moreover, the cuticle in Schoenorchis is several times thicker than those reported for other epiphytic orchids like Ascochilus, Bulbophyllum, Epidendrum, Dendrobium, Thrixspermum and Vanda (Yang et al. 2016; Kowsalya et al. 2017; Muthukumar and Shenbagam 2017, 2018; Rindyastuti et al. 2018). The cuticle is a hydrophobic covering made up of cutin and solvent soluble cuticular waxes. This covering plays an important role in effectively controlling the loss of water from the cell interior, protects against radiation and biotic stresses (Mill and Stark Schilling 2009; Hen-Avivi et al. 2014). In addition, cuticle development has been shown to be closely related to cell patterning and organ development (Shi et al. 2013). According to Haworth and McElwain (2008), the occurrence of cuticle on the leaf surface is an indication of aridity. The thick cuticle on S. nivea aerial parts prevents water loss and improves the efficiency of water when it is scarce (Guan et al. 2011). Yang et al. (2016) also suggested that the presence of thick cuticle is one of the strategies adopted by epiphytic orchids to maintain the water balance. In the present study, the cuticle was

Table 6. F-values from three-way ANOVA for epidermis cell length, width and cuticle thickening in both sides of Schoenorchis nivea leaf and leaf sheath. Numerator and denomenator difference is presented as subscripts in paranthesis.

\begin{tabular}{|c|c|}
\hline Source & $F$-value \\
\hline Plant parts $(1,348)$ & $102.990 * * *$ \\
\hline Surface $_{(1,348)}$ & $597.779 * \star *$ \\
\hline Cell dimension $(1,348)$ & $1104.3^{\star \star \star}$ \\
\hline Plant parts $\times$ Surface $_{(1,348)}$ & $52.546 * \star *$ \\
\hline Plant parts $\times$ Cell dimension $n_{(1,348)}$ & $75.120 * \star *$ \\
\hline Surface $\times$ Cell dimension $(1,348)$ & $66.878 * \star *$ \\
\hline Plant parts $\times$ Surface $\times$ Cell dimension $(1,348)$ & $24.350 * \star \star$ \\
\hline
\end{tabular}

Plant parts- Leaf and Leaf sheath, Sides- adaxial and abaxial Cell dimensionLength, Width, cuticle thickening. ${ }^{* *}$ significant at $\mathrm{P}<0.001$ thickest on the abaxial surface of the leaf sheath which was $56.49 \%$ and $77.01 \%$ thicker than the cuticle covering the adaxial and abaxial surface of the leaves respectively and $45.56 \%$ thicker than those covering the stem. Some of the leaf anatomical characters $S$. nivea shares with $S$. gemmata include paracytic stomata, water-storage cells with banded thickenings, and fibrous caps bordering xylem and phloem. However, cuticle papillae, conjunct vascular bundles, and cuticularized guard cells reported in leaves of $S$. gemmata was absent in S. nivea (Angela et al. 2015). Similarly, the absence of hypodermis and fiber bundles, homogenous mesophyll and sclerenchymatous caps bordering xylem and phloem resembles the leaves of Vandeae members. However, S. nivea differs from other Vandean taxa in amphistomatous condition and absence of glandular hairs, distinct bundle sheath, and stegmata associated with the vascular tissue (Carlsward et al. 2006).

Despite the widespread occurrence of hypostomatic in many orchids, S. nivea had an amphistomatal leaves. Amphistomatal condition is also reported in other epiphytic orchids like Acampe, Aerides, Bulbophyllum, Rhynchostylis, and Vanda (Muthukumar and Shenbagam 2017; Mulgaonkar 2005a,b; Sonowal and Baruah 2010). Richardson et al. (2017) suggested that the existence of amphistomatic condition has a strong relationship with the environment based on their commonality in high light and/or dry environments. In addition, amphistomatic leaves have an advantage of increased $\mathrm{CO}_{2}$ conductance for photosynthesis and efficient supply water to both the surfaces of the leaves (Buckley et al. 2015). The stomata in S. nivea were smaller and less dense than some of the epiphytic orchids. For example, the stomatal aperture dimensions in S. nivea were several folds smaller than those reported for some Vandoideae members. The stomatal index of $7.06 \%$ in $S$. nivea is higher than S. gemmata (5\%) reported by Angela et al. (2015). Zhang et al. (2016) indicated that plants with small and dense stomata respond more rapidly to changes in the environment or to the reduction in leaf water potential than those with larger stomata. 
Moreover, the results of that study also indicated that evergreen epiphytic orchids were better adapted to cope with water limitations during the growing season than the deciduous conspecifics (Zhang et al. 2016). This condition is generally advantageous for evergreen orchids like $S$. nivea occurring in monsoonal dry environments.

Limited studies have examined the stem anatomy of orchids than root and leaves (Kowsalya et al. 2017; Balachandar et al. 2019). Stems of S. nivea possess a thick cuticle which is in accordance with the observation of Kowsalya et al. (2017) in Vandas growing in south India. The hardy stem of $S$. nivea was completely covered by the leaf sheath as in Luisia, where, the leaf sheath covered almost the entire internode (Balachandar et al. 2019). Further, Muthukumar and Shenbagam (2017) suggested that leaf sheath aids in adding stiffness to the stem based on the difference in the thickness of the cuticle on the stems that were covered and uncovered by leaf sheath. The hard woody nature of the stem in $S$. nivea arises through progressive cortical proliferation and lignification as reported in Luisia (Balachandar et al. 2019). The uniseriate epidermis in $S$. nivea also provides mechanical support in addition to the lignified cortical proliferation. The stem cortex composed of parenchymatous cells was devoid of vascular bundles as observed in Luisia species (Balachandar et al. 2019). The sclerenchymatous ground tissue comprising of vascular bundles in $S$. nivea were similar to the stems of Vanda spathulata Spr. and Vanda wightii Rchb.f. reported by Kowsalya et al. (2017). These sclerenchymatous ground tissues provide additional mechanical support to the stems (Balachandar et al. 2019). Unlike the stems of some Vandae members, the ground tissue in $S$. nivea was characterized by the absence of idioblasts containing raphides, water-storage cells and aeration units (Carlsward et al. 2006; Kowsalya et al. 2017; Balachandar et al. 2019). The vascular bundles were scattered in the ground tissue and embedded in sclerenchymatous cells. The xylem and phloem were capped by sclerenchyma cells and the size of vascular bundles tended to be larger in the centre as reported in several species of Luisia, Vanda and Epidendrum radicans Pav. ex Lindl. (Muthukumar and Shenbagam 2017; Kowsalya et al. 2017; Balachandar et al. 2019).

Roots of $S$. nivea are mostly attached to the substratum. These roots were cylindrical and not much flattened in regions that were attached to the substratum. The substrate roots bear root hairs that were often branched. This is in line with the observations of Balachandar et al. (2019) where the roots of epiphytic orchid Luisia tenuifolia Blume were branched. The branched root hairs could be the result of stress experienced by the root hairs (Medeiros 2006) or mutation in genes involved in the root hair formation (Schiefelbein 2000).
The size of the velamen tissue and the number of cell layers could suggest the condition in which the orchid occurs. The 2-3 layered velamen of $S$. nivea resembles those of $V$. spathulata and Luisia tristis Hook.f. of the tribe Aeridinae (Kowsalya et al. 2017; Balachandar et al. 2019). The few layered velamen tissue may be the result of humid conditions in which $S$. nivea occurs. All the cells of the exovelamen and endovelamen in S. nivea possessed striations and wall thickenings. The striations were of type IIA according to Sanford and Adanlawo (1973) classification of velamen striations. The thickened walls render mechanical support to the velamen cells by preventing cell collapse during dehydration (Oliveira and Sajo 1999).

The uniseriate exodermis in S. nivea was dimorphic comprising of long and short cells. Similarly, Muthukumar and Kowsalya (2017) also observed long and short exodermal cells in substrate roots of Acampe praemorsa (Rox.) Blatt. \& McCann. Although the importance of long exodermal cells is unknown, Pridgeon (1982) reported that long cells give rise to secondary wall thickenings during maturity and die. Further, the long cells of exodermis in plants could be helpful to tolerate drought (Chimungu et al. 2014). The exodermal cells were larger than the velamen cells in $S$. nivea which resembles with the Vanda-type of velamen according to Porembski and Barthlott (1988) classification of velamen radicum. The exodermal proliferations unlike reported in some of members of Aeridinae subtribe, (Carlsward et al. 2006, Muthukumar and Kowsalya 2017) was not observed in any of the $S$. nivea roots examined. The exodermal cell thickenings in $S$. nivea may prevent the loss of water through transpiration (Benzing et al.1982). The exodermis is interrupted by thin-walled passage cells in S. nivea as observed in the roots of Luisia species and other members of Vandeae tribe (Balachandar et al. 2019). The nutrients and water transferred into the cortical cells through the thin-walled exodermal passage cells (Benzing et al. 1982, Bercu et al. 2011). Moreover, Chomichi et al. (2014) suggested that the distribution and frequency of passage cells in the exodermis might be a strategy adopted by orchids to localize and control fungal invasion. Tilosomes are absent in the roots of $S$. nivea as reported for some of the orchid species in Aeridinae (Carlsward et al. 2006). However, Leitgeb (1864) observed tilosomes in some members of Vandaceous taxa. The cover cells are present above the exodermal layer which is similar to the observations of Carlsward et al. (2006) and Kowsalya et al. (2017) in roots of some Vanda species. These cover cells are associated with the condensation of gases and water (Pridgeon 1987).

The cortex in $S$. nivea is parenchymatous (Kowsalya et al. 2017; Balachandar et al. 2019). The water-storage cells with banded thickening in $S$. nivea are similar to those observed by Carlsward et al. (2006) and Balachandar et 
al. (2019) in the roots of Vandeae members. The waterstorage cells with uniformly thickened walls can enhance the apoplastic movement of substance in the vascular tissues (Kowsalya et al. 2017). In epiphytic habitats, the rooting zones are limited to small patches of organic matter accumulating on the branches. These patches get soaked with water during rain and then quickly dry off. So epiphytic plants like orchids that are able to maintain constant water content in their tissues independent of fluctuating water content of the rooted medium have a selective advantage (Tulyananda and Nilsen 2017). The cortical cells are thin-walled in S. nivea. Nevertheless, wall thickenings in the root cortical cells were recorded in species of Aeridinae subtribe (Carlsward et al. 2006, Kowsalya et al. 2017) which contradicts with the results of the present study. Idioblasts comprising of raphides are present in the root cortex of S. nivea. The function of raphides in roots is yet to be ascertained (Balachandar et al. 2019). Nevertheless, their function in leaves and stem are well documented (Paiva and Machado 2005; Moreira et al. 2013).

The endodermis was uniseriate and $\mathrm{O}$-thickened in $S$. nivea as observed in the endodermal cells of roots in other species of Vandeae (Carlsward et al. 2006; Kowsalya et al. 2017; Balachandar et al. 2019). The endodermal cell walls were heavily thickened in S. nivea. This is in accordance with Balachandar et al. (2019), who also revealed the presence of thick-walled endodermal cells in Luisia pulniana Vatsala roots. Nevertheless, most of the Vandeae taxa exhibit thin to slightly thick endodermal cell walls, and endodermis interrupted by thin-walled passage cells oriented towards the xylem. Similarly, cells of the pericycle are thick-walled opposite to the phloem tissue. The arrangement and orientation of cells in endodermis and pericycle in $S$. nivea are similar to other epiphytic orchid species of Vandeae taxa (Kowsalya et al. 2017; Balachandar et al. 2019). The thickenings in the endodermal cell walls act as an apoplastic barrier for water and nutrient transport and protect vascular bundles from pathogens (Moreira and Isaias 2008; Muthukumar and Kowsalya 2017).

The number of xylem arches (9-11) in S. nivea is in line with the observations of Carlsward et al. (2006) who also reported 9-12 xylem arches in Neofinetia of Aeridinae. Like in other Vandeae members, the vascular tissues in $S$. nivea were embedded in the sclerenchymatous cells. The sclerenchymatous cells enclosing the phloem patches were heavily thickened than those cells around the xylem (Kowsalya et al. 2017; Balachandar et al. 2019). In most of the epiphytic orchids, the occurrence of vascular elements in the sclerenchyma cells is considered as an anatomical feature that is related with drought tolerance (Nawaz et al. 2013; Muthukumar and Shenbagam 2017). Pith in $S$. nivea was of sclerenchymatous enclosing intercellular spaces as observed in the Vandeae taxa (Carlsward et al. 2006). However, parenchymatous pith was reported in $L$. tenuifolia (Balachandar et al. 2019). Cell inclusions such as silica bodies and starch grains are absent in pith of $S$. nivea. In contrast, many members of Vandeae are characterized by the presence of such cell inclusions (Carlsward et al 2006; Balachandar et al. 2019).

Mycorrhizal colonization in S. nivea was evident in the root portions that were attached to the substrate which is in line with the observations of Sathiyadash et al. (2012) and Muthukumar and Kowsalya (2017) in various epiphytic and terrestrial roots. The fungal hyphae entered $S$. nivea roots through root hairs and traversed the velamen tissue and passage cells of exodermis and then moved into cortical cells where the fungal hyphae formed highly coiled structures called pelotons. Both degenerating and intact pelotons was observed in the root cortex. This is in accordance with the observations reported for epiphytic orchids (Sathiyadash et al. 2012; Kowsalya et al. 2017). It is well known that intact pelotons act as a reservoir for the exchange of nutrient between the orchid and fungus (Dearnalay et al. 2012). The total root length colonization was $50 \%$ in $S$. nivea with a high proportion of degenerating pelotons when compared to the intact pelotons. This suggests that $S$. nivea could have adopted mixotrophic mode of nutrition as it occurs in shady regions as observed for L. tenuifolia and L. tristis. This could have been the reason for the higher percentage of degenerating pelotons in $S$. nivea as suggested by Balachandar et al. (2019).

\section{Conclusion}

Schoenorchis nivea exhibited anatomical traits in all the vegetative parts that enable it to survive in the epiphytic habitats. These include thick-walled cuticle covering the entire surface of the leaves, leaf sheath, and the stem, abundant water-storage cells in all the vegetative parts except stem, well developed velamen tissue, presence of cover cells and thick-walled exodermis and endodermis in the roots. All the anatomical characteristics directed towards the acquisition and prevention of water loss could be attributed to the adaptation of S. nivea to the xeromorphic conditions of the epiphytic habitat. Moreover, the results of the study clearly revealed that the dimensions of the same structures occurring in different plant parts could vary significantly. In addition, the presence of mycorrhizal association along with the large proportion of degenerating pelotons in the roots suggests that $S$. nivea could adopt a mixotrophic mode of nutrition. Further anatomical and mycorrhizal investigations of other spe- 
cies of the Schoenorchis could help in the understanding of the precise adaptation of these taxa to epiphytic habitats and resource acquiring strategies.

\section{Acknowledgments}

We thank the Director, Indian Cardamom Research Institute (ICRI) Myladumpara, Idukki district, Kerala for permitting to collect the plants in ICRI campus. We also like to thank Dr. K. Dhanapal and Mr. P. Karthi for assisting during the plant collection. We thank Dr. R. Manigandan, Scientist D, i/c, Botanical Survey of India, Southern circle, Coimbatore, India for authenticating the orchid specimen.

\section{References}

Adhikari YP, Fischer HS, Fischer A (2012) Host tree utilization by epiphytic orchids in different land-use intensities in Kathmandu valley, Nepal. Plant Ecol 213:393-1412.

Angela N, Chowlu K, Sharma BH, Rao NA, Vij SP (2015) Anatomy of some terete-leaved orchid species. Kasetsart J Nat Sci 49:13-21.

Arditti J, Ghani A (2000) Tansley Review No. 110. Numerical and physical properties of orchid seeds and their biological implications. New Phytol 145:367-421.

Atwood JT (1986) The size of the Orchidaceae and the systematic distribution of epiphytic orchids. Selbyana 9:171-186

Balachandar M, Koshila Ravi R, Ranjithamani A, Muthukumar T (2019) Comparative vegetative anatomy and mycorrhizal morphology of three South Indian Luisia species (Orchidaceae) with the note on their epiphytic adaptations. Flora 251:39-61.

Balan AP, Harikrishnan S (2017) Floristic diversity of the Indian Cardamom Research Institute campus, Myladumpara, Western Ghats, India. J Threat Taxa 9:1080410822.

Benzing DH, Ott DW, Friedman WE (1982) Roots of Sobralia macrantha (Orchidaceae): Structure and function of the velamen-exodermis complex. Am J Bot 69:608-614.

Benzing DH (2000) Bromeliaceae: profile of an adaptive radiation. Cambridge, UK: Cambridge University Press.

Bercu R, Livia A, Broască B (2011) Anatomical aspects of Phalaenopsis amabilis (L.) Blume. Ann Rom Soc Cell Biol 16:102-109.

Bertolini V, Cruz-Blasi J, Damon A, Mora JV (2014) Seasonality and mycorrhizal colonization in three species of epiphytic orchids in southeast Mexico. Acta Bot Bras 28:512-518.

Buckley TN, John GP, Scoffoni C, Sack L (2015) How does leaf anatomy influence water transport outside the xylem? Plant Physiol 168:1616-1635.

Carlsward BS (2014) Campylocentrum. In: Pridgeon AM, Cribb PJ, Chase MW, Rasmussen FN (Eds.) Genera Orchidacearum. Vol. 6. Oxford University Press, Oxford. pp. 370-372.

Carlsward BS, Stern WL, Bytebier B (2006) Comparative vegetative anatomy and systematics of the angraecoids (Vandeae, Orchidaceae) with an emphasis on the leafless habit. Bot J Linn Soc 151:165-218.

Chimungu JG, Brown KM, Lynch JP (2014) Large root cortical cell size improves drought tolerance in maize. Plant Physiol 166:2166-2178.

Chomicki G, Bidel LPR, Jay-Allemand C (2014) Exodermis structure controls fungal invasion in the leafless epiphytic orchid Dendrophylax lindenii Lindl. Benth. ex Rolfe. Flora 209:88-94.

Dearnaley JDW, Martos F, Selosse MA (2012) Orchid mycorrhizas: molecular ecology, physiology, evolution and conservation aspects. In Esser K (Ed.), The Mycota, Vol. IX -Fungal Associations, 2nd ed. Springer-Verlag, Berlin, Germany, pp. 207-230.

ENVIS Centre on Floral Diversity (2019) CITES Plants. Botanical Survey of India, Kolkata, West Bengal, India (http://www.bsienvis.nic.in/Database/bsi_3949.aspx) accessed on $16^{\text {th }}$ January 2019.

Guan ZJ, Zhang SB, Guan KY, Li SY, Hu H (2011) Leaf anatomical structures of Paphiopedilum and Cypripedium and their adaptive significance.J Plant Res 124:289-298.

Haworth M, McElwain J (2008) Hot, dry, wet, cold or toxic? Revisiting the ecological significance of leaf and cuticular micromorphology. Palaeogeogr Palaeoclimatol Palaeoecol 262:79-90.

Hen-Avivi S, Lashbrooke J, Costa F, Aharoni A (2014) Scratching the surface: genetic regulation of cuticle assembly in fleshy fruit. J Exp Bot 65:4653-4664.

Johanson DA (1940) Plant microtechnique. McGrew Hill Book, New York and London, pp.523.

Kigkr RW (1971) Epidermal and cuticular mounts of plant material obtained by maceration. Stain Technol 46:71-75.

Koske RE, Gemma JN (1989) A modified procedure for staining roots to detect VA mycorrhizas. Mycol Res 92:486-505.

Kowsalya A, Rojamala K, Muthukumar T (2017) Comparative vegetative anatomy of South Indian Vandas, Orchidaceae. Flora 235:59-75.

Kumar M, Sequiera S (2000) A new species of Schoenorchis (Orchidaceae) from India. Kew Bulletin 55:241-244.

Lallemand F, Figura T, Damesin C, Fresneau C, Griveau C, Fontaine N, Zeller B, Selosse M (2019) Mixotrophic orchids do not use photosynthates for perennial underground organs. New Phytol 221:12-17.

Leitgeb H (1864) Die Luftwurzeln der Orchideen: Denk- 
schriften der KaiserlichenAkademie der Wissenschaften. Math Naturwiss K1 24:179-222.

Lux A, Morita S, Abe J, Ito K (2005) Improved method for clearing and staining free-hand sections and wholemount samples. Ann Bot 96:989-996.

Mathew J, George KV (2015) Checklist of orchids of Kottavasal Hills in Achancoil Forests, Southern Western Ghats, (Kollam, Kerala), India. Threat Taxa 7:7691-7696.

McGonigle TP, Miller MH, Evans DG, Fairchild GL, Swan JA (1990) A new method which gives an objective measure of colonization of roots by vesicular-arbuscular mycorrhizal fungi. New Phytol 115:495-501.

Medeiros JD (2006) Branched root hairs in Miconia albicans (Sw.) Triana (Melastomaceae). Insula 35: 85-94.

Mill RR, Stark Schilling DM (2009) Cuticle micromorphology of Saxegothaea (Podocarpaceae). Bot J Linn Soc 159:58-67.

Moreira AS, Isaias RM (2008) Comparative anatomy of the absorption roots of terrestrial and epiphytic orchids. Braz Arch Biol Technol 51:83-93.

Moreira AS, Filho JP, Isaias RM (2013) Structural adaptations of two sympatric epiphytic orchids (Orchidaceae) to a cloudy forest environment in rocky outcrops of Southeast Brazil. Rev Biol Trop 61:1053-1065.

Mulgaonkar MS (2005a) Studies on dermal anatomy of three corticolous orchids from India. Int J Mendel 22:105-106.

Mulgaonkar MS (2005b) Dermal anatomy of some species of genus Aerides Lour. from Maharashtra. Int J Mendel 22:107-108.

Muthukumar T, Kowsalya A (2017) Comparative anatomy of aerial and substrate roots of Acampe praemorsa Rox Blatt and MC Cann. Flora 266:17-28.

Muthukumar T, Shenbagam M (2017). Vegetative anatomical adaptations of Epidendrum radicans (Epidendroideae, Orchidaceae) to epiphytic conditions of growth. Mod Phytomorphol 11:117-130.

Muthukumar T, Shenbagam M (2018) Vegetative anatomy of the orchid Bulbophyllum Sterile (Orchidaceae: Epidendroideae). Lankesteriana 18:13-22.

Nawaz A, Farooq M, Cheema SA, Wahid A (2013) Differential response of wheat cultivars to terminal heat stress. Int J Agric Biol 15:1354-1358.

Nurfadilah S, Swarts ND, Dixon KW, Lambers H, Merritt DJ (2013) Variation in nutrient-acquisition patterns by mycorrhizal fungi of rare and common orchids explains diversification in a global biodiversity hotspot. Ann Bot 111:1233-1241.

Oliveira VC, Sajo MG (1999) Root anatomy of nine Orchidaceae species. Braz Arch Biol Technol 42:405-413.

Paiva EA, Machado SR (2005) Role of intermediary cells in Peltodon radicans (Lamiaceae) in the transfer of calcium and formation of calcium oxalate crystals. Braz Arch Biol Technol 48:147-153.
Porembski S, Barthlott W (1988) Velamen radicum micromorphology and classification of Orchidaceae. Nord J Bot 8:117-137.

Pridgeon AM (1982) Diagnostic anatomical characters in the Pleurothallidinae (Orchidaceae). Am J Bot 69:921-38.

Pridgeon AM (1987) The velamen and exodermis of orchid roots. In: Arditti, J. (Ed.), Orchid Biology-Reviews and Perspectives. Cornell University Press, Ithaca, NY, pp. 139-192.

Pridgeon AM, Cribb PJ, Chase MW, Rasmussen FN, (Eds). (2009) Genera Orchidacearum, vol. 5: Epidendroideae (part 2). Oxford University Press, Oxford. p.585.

Richardson F, Brodribb TJ, Jordan GJ (2017) Amphistomatic leaf surfaces independently regulate gas exchange in response to variations in evaporative demand. Tree Physiol 37:869-878.

Rindyastuti R., Nurfadilah S, Rahadiantoro A, Hapsari L, Abywijaya IK (2018) Leaf anatomical characters of four epiphytic orchids of Sempu Island, East Java, Indonesia: The importance in identification and ecological adaptation. Biodiversitas 19:1906-1918.

Salisbury EJ (1927) On the causes and ecological significance of stomatal frequency, with special reference to the woodland flora. Philos Trans Royal Soc B 216:1-65.

Sanford WW, Adanlawo I (1973) Velamen and exodermis characters of West African epiphytic orchids in relation to taxonomic grouping and habitat tolerance. Bot J Linn Soc 66:307-321.

Sathiyadash K, Muthukumar T, Uma E, Pandey RR (2012) Mycorrhizal association and morphology in orchids. J Plant Interact 7:238-247.

Schiefelbein JW (2000) Constructing a plant cell. The genetic control of root hair development. Plant Physiol 124:1525-1531.

Selosse MA, Martos F (2014) Do chlorophyllous orchids heterotrophically use mycorrhizal fungal carbon? Trends Plant Sci 19:683-685.

Shi JX, Adato A, Alkan N, He Y, Lashbrooke J, Matas AJ, Meir S, Malitsky S, Isaacson T, Prusky D, Leshkowitz D, Schreiber L, Granell AR, Widemann E, Grausem B, Pinot F, Rose JKC, Rogachev I, Rothan C, Aharoni A (2013) The tomato SISHINE3 transcription factor regulates fruit cuticle formation and epidermal patterning. New Phytol 197:468-480.

Smith S, Read D (2008) Mycorrhizal Symbiosis. Academic press, London, pp. 800.

Sonowal J, Baruah A (2010) Foliar epidermis of twenty orchid species from Northeast India with emphasis to their taxonomy. Pleione 4:163-171.

Stpiczyńska M, Davies KL, Kaminska M, (2011) Comparative anatomy of the nectary spur in selected species of Aeridinae (Orchidaceae). Ann Bot 107:327-345.

Tulyananda T, Nilsen ET (2017) The role of idioblasts in 
leaf water relations of tropical Rhododendron. Am J Bot $104: 828-39$.

Van Cotthem WRJ (1970) A classification of stomatal types. Bot J Linn Soc 63:235-246.

Yang SJ, Sun M,Yang QY, Ma RY, Zhang JL, Zhang SB (2016) Two strategies by epiphytic orchids for maintaining water balance: thick cuticles in leaves and water storage in pseudobulbs. AoB Plants 8: plw046.
Zhang W, Hu H, Zhang SB (2016) Divergent adaptive strategies by two co-occurring epiphytic orchids to water stress: escape or avoidance? Front Plant Sci 7:1-11.

Zhong M, Shao X, Wu R, Wei X, Van L, Richard SP, Cornelissen, Johannes HC (2018) Contrasting altitudinal trends in leaf anatomy between three dominant species in an alpine meadow. Aus J Bot 66:448-458. 
